\title{
In situ-Mercury Film Electrode for Simultaneous Determination of Lead and Cadmium Using Nafion Coated New Coumarin Schiff Base as Chelating-Adsorbent
}

\author{
Nelson Nuñez-Dallos ${ }^{1}$, Carol Cuadrado ${ }^{2}$, John Hurtado ${ }^{1, *}$, Edgar Nagles, ${ }^{2, *}$, Olimpo García-Beltran ${ }^{2}$ \\ ${ }^{1}$ Departamento de Química, Universidad de los Andes, Carrera 1 No. 18A-12, Bogotá, Colombia \\ ${ }^{2}$ Facultad de Ciencias Naturales y Matemáticas, Universidad de Ibagué, Carrera 22 Calle 67, Ibagué, \\ Colombia \\ *E-mail: edgar.nagles@unibague.edu.co, jj.hurtado@uniandes.edu.co
}

doi: $10.20964 / 2016.12 .02$

Received: 1 September 2016 / Accepted: 25 September 2016 / Published: 10 November 2016

Reaction of $o$-phenylenediamine and 8-formyl-7-hydroxycoumarin yield a new coumarin salen ligand, (CSB) which was isolated as orange air-stable solid and characterized by melting point, thermogravimetric analysis (TGA), mass spectra, infrared and NMR $\left({ }^{1} \mathrm{H},{ }^{13} \mathrm{C}\right)$ spectroscopy. New CSB was dispersed in nafion and nafion-CSB composite was deposited on a glassy carbon electrode. The modified electrode nafion-CSB/GCE allowed the formation in-situ of mercury film for detection of $\mathrm{Pb}$ (II) and Cd(II) by anodic stripping voltammetry (ASV) in buffer phosphate solution pH 3.0 and 4.0. Optimal conditions were studied (mercury concentration: $\mathrm{C}_{\mathrm{Hg}} 40.0 \mathrm{mg} \mathrm{L}^{-1}$; CSB concentración; $\mathrm{C}_{\mathrm{CSB}}$; $20.0 \mu \mathrm{mol} \mathrm{L}^{-1}$; $\mathrm{pH} 3.0$ and $\mathrm{pH} 4.0 ; \mathrm{E}_{\mathrm{ACC}}:-1.1 \mathrm{~V}$ and $\left.\mathrm{t}_{\mathrm{ACC}}: 80\right)$. The detection limit $(3 \sigma / \mathrm{b})$ for $\mathrm{Pb}$ (II) $\mathrm{Cd}$ (II) were of $0.15 \mu \mathrm{g} \mathrm{L}^{-1}$ for $\mathrm{Pb}$ (II) and $\mathrm{Cd}$ (II) at $\mathrm{pH} 3.0$. Moreover, 0.071 and $0.080 \mu \mathrm{g} \mathrm{L}^{-1}$ for $\mathrm{Pb}$ (II) and $\mathrm{Cd}(\mathrm{II})$, respectively at $\mathrm{pH} 4.0$, The method was validated using ICP multi-element standard solution IX (Merck) containing As, Be, Cd, Cr(VI), Hg, Ni, Pb, Se and Tl $100 \mathrm{mg} \mathrm{L}^{-1}$. Finally, river, tap and mineral waters were analyzed.

Keywords: Schiff base, 7-hydroxycoumarin, Anodic stripping voltammetry, Modified electrode, Lead, Cadmium, water samples

\section{$\underline{\text { FULL TEXT }}$}

(C) 2016 The Authors. Published by ESG (www.electrochemsci.org). This article is an open access article distributed under the terms and conditions of the Creative Commons Attribution license (http://creativecommons.org/licenses/by/4.0/). 